Reprod. Nutr. Dévelop., 1985, 25 (4 A), 705-716.

\title{
Effect of wheat bran and pectin on the absorption and retention of phosphorus, calcium, magnesium and zinc by the growing pig.
}

\author{
S. BAGHERI, L. GUÉGUEN \\ with the technical assistance of Pierrette CAMUS
}

Station de Recherches de Nutrition, I.N.R.A., 78350 Jouy-en-Josas, France.

Summary. Two separate balance experiments of $\mathrm{P}, \mathrm{Ca}, \mathrm{Mg}$ and $\mathrm{Zn}$ were carried out on 5 lots of 4 growing pigs each $(35-40 \mathrm{~kg}$ ) adapted for 3 weeks to one of the diets studied. In the first experiment, the control diet was compared with a diet containing $20 \%$ of coarse wheat bran, thus richer in minerals, the quantities ingested not being equalized. In the second experiment, three diets were compared : a control diet, a diet with $2.5 \%$ of highmethoxylated (HM) apple pectin, and a diet with $2.5 \%$ low-methoxylated (LM) apple pectin.

The supplement of $\mathrm{P}$ and $\mathrm{Mg}$ provided by the wheat bran was well absorbed (apparent absorption) and retained by the pigs. On the contrary, in spite of higher intake of $\mathrm{Ca}$ and $\mathrm{Zn}$ with bran diet, the absorption of these minerals was not improved. The action of wheat bran phytase and the possible absorption of $\mathrm{P}$ and $\mathrm{Mg}$ (but not of $\mathrm{Ca}$ and $\mathrm{Zn}$ ) in the large intestine could explain these results.

Compared to HM pectin that had relatively little effect on mineral utilization, LM pectin drastically diminished the absorption and retention of the minerals studied and resulted in negative $\mathrm{Ca}, \mathrm{Mg}$ and $\mathrm{Zn}$ balances. The degree of pectin esterification would thus be the main factor determining the effect of pectin on mineral availability.

In conclusion, wheat bran is a source of available $\mathrm{P}$ and $\mathrm{Mg}$ for the pig but it might have an unfavorable effect on the utilization of $\mathrm{Ca}$ and $\mathrm{Zn}$. LM pectin produces a deleterious influence on mineral balances.

\section{Introduction.}

The well-known beneficial action of dietary fibers should not mask their putative unfavorable effects on the biological availability of some nutrients, especially minerals. Since the earliest work of Mellanby on dogs in 1921, many authors have shown the rachitogenic effect in humans and domestic animals of diets with high levels of whole cereals. The factor responsible was soon identified as phytic acid, abundant in seed envelopes ; this was confirmed in many balance experiments beginning with McCance and Widdowson in 1942 and continuing with Walker, Fox and Irving in 1948. More than 20 years later, Reinhold (1971) showed multiple mineral deficiencies, particularly of zinc, in rural populations in southern Iran which ate whole, unleavened bread, and Wills et al. (1972) attributed to phytic acid the rickets found among certain immigrants in England. 
The inhibitory effect of the properly so-called fibers of cereals on the utilization of minerals has been reported by Phandis and Sohonie (1974) and by Reinhold et al. (1975), suggesting that fibers rather than phytates determined the availability of minerals, while Davies, Hristic and Flett (1977) and Andersson et al. (1983), again attributed the deleterious effect of cereal diets to phytic acid. Nevertheless, the work in vitro of James, Branch and Southgate (1978), showing the strong binding capacity of ionized carboxyl groups of uronic acids, gives an explanation for the effect on minerals of other constituents of dietary fibers, such as hemicelluloses and pectins.

As regards human nutrition, the practical importance of this fiber-mineral interaction has not yet been elucidated, partly due to the small number of balance experiments carried out on humans and also due to the difficulty in extrapolating to humans results obtained in rats. In the latter, the phytase of the intestinal mucosa (Bitar and Reinhold, 1972) or that of bacteria of the large intestine (Wise and Gilburt, 1982) is known to hydrolize phytates, which would explain why wheat bran does not always have an unfavorable effect in this species (Bagheri and Guéguen, 1981, 1982). Pigs, which have no intestinal phytase (Pointillart, Fontaine and Thomasset, 1984) and show signs of $\mathrm{Ca}$ and $\mathrm{Zn}$ deficiency when the diet contains a high level of phytates, are thus better models for mineral studies applied to human nutrition.

The first experiment of the present study tried to investigate and explain the effect of wheat bran on the utilization of $\mathrm{P}, \mathrm{Ca}, \mathrm{Mg}$ and $\mathrm{Zn}$ in pigs. As bran is also rich in some minerals and as this supply could be beneficial, we compared a diet containing $20 \%$ of bran with a control diet which we purposely did not supplement with minerals. Accordingly, it attempted to estimate the efficiency of the intrinsic minerals of the bran and the effect of this supply on mineral balances.

The effect of pectin on mineral metabolism is not as well-known and, to our knowledge, has never been studied in pigs. A second experiment was thus designed to compare the effects of two pectins of different degrees of esterification at the same mineral intakes.

The results obtained have already been partially and briefly published (Bagheri and Guéguen, 1983) but have never been presented in full.

\section{Material and methods.}

1. Wheat bran and pectins. - The standard wheat bran was prepared by "Les Grands Moulins de Paris " and the mean size of the particles was $660 \mu \mathrm{m}$. Its main constituents (Briliouet and Thibault, 1981) were, in \% of raw product : water 9.8 and, in \% of dry matter : ash 6.6, protein $(N \times 5.7) 13.6$, starch 11.3, pentose polymers 22.9 , cellulose 10.0 , lignin 7.9 . It contained, in $\mathrm{g}$ per $\mathrm{kg}$ dry matter : total $\mathrm{P} 12.9$, phytic $\mathrm{P} 8.9, \mathrm{Ca} 1.0, \mathrm{Mg} 4.7$ and $\mathrm{Zn} 0.073$.

The pectin (Unipectine, Paris), extracted from apple pulp, had two different degrees of esterification : $72.5 \%$ for the high-methoxylated (HM) pectin and 
$39.9 \%$ for the low-methoxylated (LM) pectin. The chemical characteristics of the two pectins (Brillouet and Thibault, 1981) are given in table 1.

TABLE 1

Characteristics of the pectins (in \%).

\begin{tabular}{lcc}
\hline & HM pectin & LM pectin \\
\hline Water & 8.9 & 9.7 \\
Protein $(\mathrm{N} \times 6.25)$ & 1.5 & 0.7 \\
Neutral sugars & 21.7 & 13.9 \\
Anhydrogalacturonic acids & 63.7 & 64.9 \\
Methoxyls & 8.1 & 4.6 \\
Degree of esterification & 72.5 & 39.9 \\
\hline
\end{tabular}

2. Diets. - The formulas and analytical mineral compositions of the diets used are given in tables 2 and 3 , respectively. The control diet was a conventional mixture of corn and soybean meal, to which $20 \%$ of wheat bran was added (experimental diet) at the expense of the corn. To facilitate the interpretation of the results on bran mineral utilization, the corresponding control diet was not supplemented with minerals, except for sodium and calcium which were too low ; the latter however was not added sufficiently, to avoid an increase in $\mathrm{Ca}: \mathrm{P}$ imbalance. Therefore, $\mathrm{Ca}$ and $\mathrm{P}$ levels in the control diet (table 3 ) were lower than the French recommendations for growing pigs (Guéguen and Perez, 1981) but were sufficient for a limited period of normal growth. The bran diet thus had a much higher mineral content than the control diet.

TABLE 2

Diet formulas $(\%)$.

\begin{tabular}{|c|c|c|c|c|c|}
\hline & \multicolumn{2}{|c|}{ Exp. 1} & \multicolumn{3}{|c|}{ Exp. II } \\
\hline & $\begin{array}{c}\text { Control } \\
1\end{array}$ & $\begin{array}{c}\text { Coarse } \\
\text { bran }\end{array}$ & $\begin{array}{c}\text { Control } \\
\text { II }\end{array}$ & $\underset{\text { pectin }}{\mathrm{HM}}$ & $\begin{array}{c}\mathrm{LM} \\
\text { pectin }\end{array}$ \\
\hline Corn & 77.5 & 57.0 & 75.5 & 74.0 & 74.0 \\
\hline Soybean & 20.0 & 20.0 & 20.0 & 20.0 & 20.0 \\
\hline Coarse bran & & 20.0 & & & \\
\hline Pectin (HM) & & & & 2.5 & \\
\hline Pectin (LM) & & & & & 2.5 \\
\hline Mineral mixture I & 1.5 & 2.0 & & & \\
\hline Mineral mixture II & & & 3.5 & 3.5 & 3.5 \\
\hline Vitamin mixture & 1.0 & 1.0 & 1.0 & 1.0 & 1.0 \\
\hline
\end{tabular}

Mineral mixture I : $\mathrm{CaCO}_{3}: 80 \% ; \mathrm{NaCl}: 20 \%$.

Mineral mixture II : $\mathrm{CaCO}_{3}: 40 \%: \mathrm{CaHPO}_{4}, 2 \mathrm{H}_{2} \mathrm{O}: 43 \% ; \mathrm{NaCl}: 15 \% ; \mathrm{ZnSO}_{4}$, $\mathrm{H}_{2} \mathrm{O}: 1.0 \% ; \mathrm{MnSO}_{4}, \mathrm{H}_{2} \mathrm{O}: 0.8 \% ; \mathrm{CuSO}_{4}, 5 \mathrm{H}_{2} \mathrm{O}: 0.2 \%$.

Vitamin mixture supplying for $100 \mathrm{~kg}$ of diet : Vitamin $A: 500000 \mathrm{IU}$; vitamine $D_{3}: 100000 \mathrm{IU}$; Vitamin E : $1500 \mathrm{IU}$; thiamin hydrochloride : $0.2 \mathrm{~g}$; riboflavin : $0.5 \mathrm{~g} ;$ ascorbic acid : $2.0 \mathrm{~g} ;$ vitamin $\mathrm{B}_{12}: 2.5 \mathrm{~g} ;$ niacin $: 2.0 \mathrm{~g} ;$ calcium pantothenate $: 2.0 \mathrm{~g}$; choline $: 50 \mathrm{~g}$.

Apple pectin was added into the diet at a rate of $2.5 \%$, a preliminary experiment having shown that higher amounts caused diarrhoea. Since pectin, unlike bran, does not contain minerals, all the diets were completed with an 
equilibrated mineral mixture. Hence, the mineral levels in the three diets (table 3 ) conformed to dietary recommendations (Guéguen and Perez, 1981).

TABLE 3

Mineral composition of the diets.

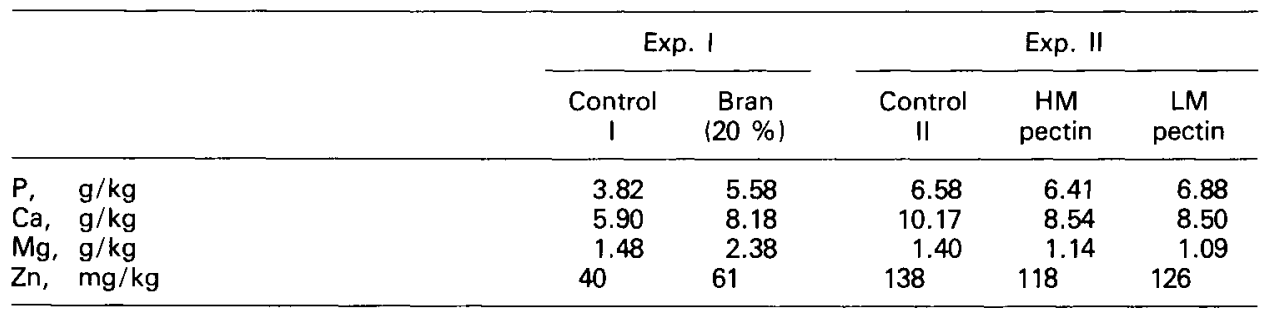

3. Animals and experimental protocol. - For the two separate experiments, twenty male Large White pigs with an average initial weight of $35 \mathrm{~kg}$ were used : 2 groups of 4 each for the bran experiment and 3 groups of 4 each for the pectin experiment. The animals were adapted during 3 weeks to one of the preceding diets, then put into individual steel metabolism cages; the urine and feces were collected separately.

The diets were distributed in two meals per day in limited quantities to avoid refusals. During the balance period, the amounts of intake were 1200 to $1250 \mathrm{~g}$ (control diet) and 1000 to $1200 \mathrm{~g}$ (control diet) of dry matter per day in the bran and the pectin experiment, respectively. Distilled water was available ad libitum.

The amounts ingested and excreted were measured every day for 10 consecutive days and fecal samples were dried at $70^{\circ} \mathrm{C}$, then ground. Various assays were carried out on the representative samples of the 10-day collections.

4. Analytical methods. - P, Ca, Mg and $\mathrm{Zn}$ were assayed on samples of diet, feces or urine after ashing in a muffle furnace at $530^{\circ} \mathrm{C}$ for about $8 \mathrm{~h}$. The ash was dissolved with pure $\mathrm{HCl}$ then, after complete evaporation, was put into a $10 \% \mathrm{HNO}_{3}$ solution. After filtration, the solutions were diluted according to the concentration of the element to be assayed.

Phosphorus was determined by ammonium phospho-vanadate colorimetry, $\mathrm{Ca}$ by flame spectrophotometry (Eppendorf) and $\mathrm{Mg}$ and $\mathrm{Zn}$ by atomic absorption spectrometry (IL 151). Phytic P was determined by a modification of the method of Oberleas (1971).

5. Statistical analysis. - The Newman-Keuls test was used for comparison of the means after variance equality had been checked by the Bartlett $\chi^{2}$-test (Snedecor and Cochran, 1967).

\section{Results.}

1. Effect of wheat bran. - After an adaptation period of 3 weeks, the behavior and appetite of the pigs were normal and the average weight gain during the balance period was 475 and $712 \mathrm{~g} /$ day for the control and $20 \%$ bran groups, respectively. 
The amounts of $\mathrm{P}, \mathrm{Ca}, \mathrm{Mg}$ and $\mathrm{Zn}$ ingested, absorbed (apparent absorption) and retained are shown in figures 1,2, 3 and 4, respectively. The corresponding values of the percentages of apparent absorption and retention are given in table 4 . Urinary excretion was negligible for $\mathrm{P}$ and $\mathrm{Ca}$ but more important for $\mathrm{Mg}$ and $\mathrm{Zn}$.

The additional supplies of $\mathrm{P}$ and $\mathrm{Mg}$ provided by bran were well absorbed and retained (figs. 1, 3). Furthermore, in spite of the higher supplies of $P$ and $M g$, the percentages of apparent absorption (AA \%) and retention ( $\%$ ) were higher with bran and the urinary excretion of $\mathrm{Mg}$ was lower.

On the contrary, the additional $\mathrm{Ca}$ supplied by the $20 \%$ of bran did not result in increased absorption and retention of this mineral (fig. 2). AA \% and $\mathrm{R} \%$ (table 5) dropped to abnormal levels in the presence of bran, though ingested values were not excessive. The bran considerably increased $\mathrm{Zn}$ ingestion but did not change its absorption and retention, the $\mathrm{Zn}$ balance not being significantly modified (fig. 4). The urinary excretion of $\mathrm{Zn}$ was lower with the bran diet.
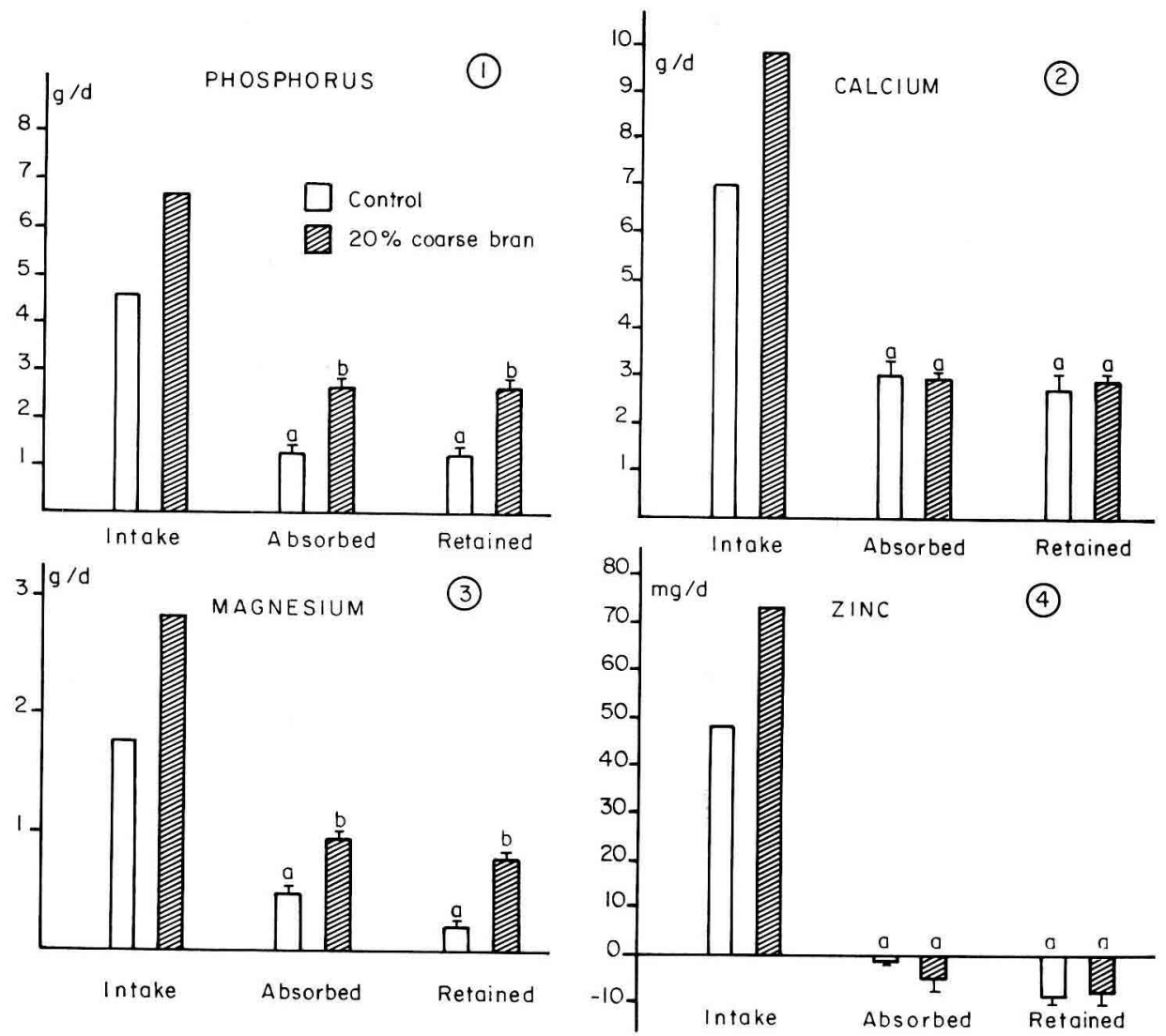

FIGS. 1, 2, 3, 4. - Effect of wheat bran on the utilization of phosphorus, calcium, magnesium and zinc in growing pigs.

$\mathrm{M} \pm \mathrm{SEM} ; \mathrm{n}=4$.

Values with the same superscript are not significantly different at $P \leqslant 0.05$.

Reproduction, nutrition, développement $n^{\circ} 4 / \mathrm{A} .-8$ 
TABLE 4

Effect of wheat bran on the percentage of apparent absorption (AA \%) and retention (R \%) of minerals in pigs.

\begin{tabular}{|c|c|c|c|c|c|}
\hline & & $\mathbf{P}$ & $\mathrm{Ca}$ & $\mathrm{Mg}$ & $\mathrm{Zn}$ \\
\hline Intake, $\mathrm{g} / \mathrm{d}$ & $\begin{array}{l}\text { Control } \\
+ \text { Bran }\end{array}$ & $\begin{array}{l}4.58 \\
6.70\end{array}$ & $\begin{array}{l}7.11 \\
9.85\end{array}$ & $\begin{array}{l}1.78 \\
2.85\end{array}$ & $\begin{array}{l}0.048 \\
0.073\end{array}$ \\
\hline \% Absorbed & $\begin{array}{l}\text { Control } \\
+ \text { Bran }\end{array}$ & $\begin{array}{l}27.5 \pm 3.4^{\mathrm{a}} \\
39.7 \pm 2.3^{\mathrm{b}}\end{array}$ & $\begin{array}{l}42.8 \pm 4.5^{\mathrm{a}} \\
30.0 \pm 1.0^{\mathrm{b}}\end{array}$ & $\begin{array}{l}28.1 \pm 3.1^{a} \\
33.2 \pm 1.7^{a}\end{array}$ & $\begin{array}{l}<0^{a} \\
<0^{a}\end{array}$ \\
\hline$\%$ Retained & $\begin{array}{l}\text { Control } \\
+ \text { Bran }\end{array}$ & $\begin{array}{l}26.9 \pm 3.4^{\mathrm{a}} \\
39.3 \pm 2.3^{\mathrm{b}}\end{array}$ & $\begin{array}{l}38.2 \pm 4.0^{\mathrm{a}} \\
29.3 \pm 1.1^{\mathrm{b}}\end{array}$ & $\begin{array}{l}12.6 \pm 1.9^{\mathrm{a}} \\
27.5 \pm 2.2^{\mathrm{b}}\end{array}$ & $\begin{array}{l}<\mathrm{O}^{\mathrm{a}} \\
<0^{\mathrm{a}}\end{array}$ \\
\hline
\end{tabular}

$M \pm \operatorname{SEM}(n=4)$.

Values in the same column with different superscripts are significantly different at $P \leqslant 0.05$.

2. Effect of pectin. - The amounts of the diets ingested spontaneously by the pigs were decreased from 1200 for the control group to $1000 \mathrm{~g}$ per day for the two pectin groups to avoid refusals. This explains the lesser amounts of minerals ingested in the two experimental groups. Average daily weight gain during the balance period was 675,475 and $650 \mathrm{~g}$ for the control, HM pectin and LM pectin groups, respectively.

The amounts of $\mathrm{P}, \mathrm{Ca}, \mathrm{Mg}$ and $\mathrm{Zn}$ ingested, absorbed (apparent absorption) and retained are shown in figures $5,6,7$ and 8 , respectively. The corresponding $A A \%$ and $R \%$ values are given in table 5 . Urinary excretion was always very low for $\mathrm{P}$ and $\mathrm{Ca}$ but relatively high for $\mathrm{Mg}$ and $\mathrm{Zn}$.

Considering the differences in the amounts ingested, it appears that incorporating $2.5 \%$ of $\mathrm{HM}$ pectin into the diet did not markedly change the utilization of the studied minerals. The decrease in the amounts of $\mathrm{Ca}$ and $\mathrm{Mg}$ absorbed and retained expressed the decrease in the amounts ingested (figs. 6, 7). On the other hand, the LM pectin highly significantly diminished the apparent absorption and retention of $\mathrm{Ca}$ and $\mathrm{Mg}(\mathrm{P} \leqslant 0.01)$ and decreased $\mathrm{P}$ and $\mathrm{Zn}$ absorption $(\mathrm{P} \leqslant 0.05)$, resulting in negative $\mathrm{Ca}, \mathrm{Mg}$ and $\mathrm{Zn}$ balances.

TABLE 5

Effect of apple pectin on the percentages of apparent absorption (AA \%) and retention (R \%) of minerals in pigs.

\begin{tabular}{|c|c|c|c|c|c|}
\hline & & $\mathrm{P}$ & $\mathrm{Ca}$ & $\mathrm{Mg}$ & $\mathrm{Zn}$ \\
\hline Intake, g/d & $\begin{aligned} & \text { Control } \\
+ & \text { Pectin HM } \\
+ & \text { Pectin LM }\end{aligned}$ & $\begin{array}{l}7.90 \\
6.41 \\
6.81\end{array}$ & $\begin{array}{r}12.23 \\
8.70 \\
8.57\end{array}$ & $\begin{array}{l}1.68 \\
1.14 \\
1.08\end{array}$ & $\begin{array}{l}0.165 \\
0.118 \\
0.125\end{array}$ \\
\hline$\%$ Absorbed & $\begin{aligned} & \text { Control } \\
+ & \text { Pectin HM } \\
+ & \text { Pectin LM }\end{aligned}$ & $\begin{array}{l}36.0 \pm 2.1^{\mathrm{ab}} \\
43.6 \pm 2.9^{\mathrm{a}} \\
24.8 \pm 5.7^{\mathrm{b}}\end{array}$ & $\begin{array}{l}36.8 \pm 1.9^{\mathrm{a}} \\
28.1 \pm 3.8^{\mathrm{a}} \\
0.42 \pm 7.5^{\mathrm{b}^{*}}\end{array}$ & $\begin{array}{c}31.7 \pm 1.3^{\mathrm{a}} \\
17.8 \pm 2.9^{\mathrm{a}} \\
< \pm 0^{\mathrm{b}^{\circ}}\end{array}$ & $\begin{array}{c}7.4 \pm 4.7^{\mathrm{a}} \\
12.3 \pm 5.9^{\mathrm{a}} \\
<0^{\mathrm{b}}\end{array}$ \\
\hline \% Retained & $\begin{aligned} & \text { Control } \\
+ & \text { Pectin HM } \\
+ & \text { Pectin LM }\end{aligned}$ & $\begin{array}{l}35.6 \pm 2.1^{\mathrm{ab}} \\
42.0 \pm 5.4^{\mathrm{a}} \\
23.8 \pm 5.7^{\mathrm{b}}\end{array}$ & $\begin{array}{c}34.2 \pm 2.0^{\mathrm{a}} \\
27.4 \pm 3.8^{\mathrm{a}} \\
<0^{\mathrm{b}^{*}}\end{array}$ & $\begin{array}{c}20.5 \pm 2.4^{\mathrm{a}} \\
10.1 \pm 3^{\mathrm{a}} \mathrm{3}^{\mathrm{a}} \\
<0^{\mathrm{b}^{*}}\end{array}$ & $\begin{array}{c}2.8 \pm 2.7^{\mathrm{a}} \\
11.0 \pm 6.1^{\mathrm{a}} \\
<0^{\mathrm{b}}\end{array}$ \\
\hline
\end{tabular}

$M \pm S E M(n=4)$.

Values in the same column with different superscripts are significantly different at $P \leqslant 0.05$.

Values with different superscripts and an asterisk are significantly different at $P \leqslant 0.01$. 

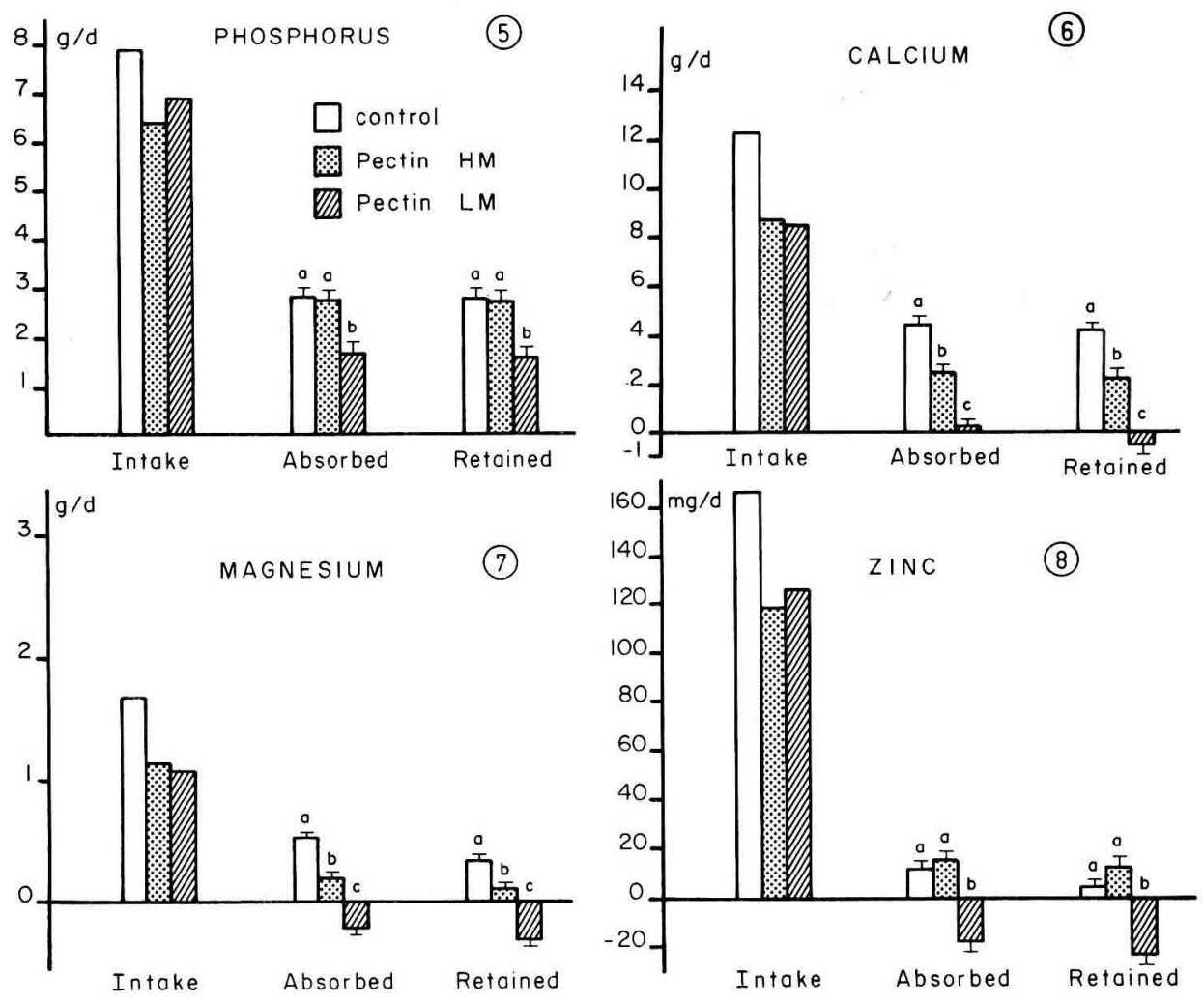

FIGS. 5, 6, 7, 8. - Effect of apple pectin on the utilization of phosphorus, calcium, magnesium and zinc in growing pigs.

$\mathrm{M} \pm \mathrm{SEM} ; \mathrm{n}=4$.

Values with the same superscript are not significantly different at $P \leqslant 0.05$.

\section{Discussion.}

1. Effects of wheat bran. - Since the main object of this experiment was the study of the effects on $\mathrm{P}, \mathrm{Ca}, \mathrm{Mg}$ and $\mathrm{Zn}$ balances of a high supply $(20 \%)$ of wheat bran, rich in minerals, the control diet contained no supplement of inorganic salts to equalize the amounts ingested. It is thus difficult to compare the percentages of absorption and retention (table 4). Nevertheless, the present results confirm the well-known fact that, in pigs, contrary to humans, with a normal intake of $\mathrm{Ca}$ and $\mathrm{P}$, urinary excretion of these two minerals is negligible since retention almost equals apparent absorption; however, this is not true for $\mathrm{Mg}$ and $\mathrm{Zn}$.

The values obtained (figs. 1, 2, 3,4) clearly demonstrate that pigs can utilize the $\mathrm{P}$ and $\mathrm{Mg}$ of wheat bran and that adding $20 \%$ of bran considerably improved these mineral balances. On the other hand, increasing supplies of $\mathrm{Ca}$ and $\mathrm{Zn}$ by the 
bran diet did not ameliorate their retention. The negative $\mathrm{Zn}$ balance obtained with the two diets shows that not only was the $\mathrm{Zn}$ level $(40 \mathrm{ppm})$ of the control diet insufficient but the $\mathrm{Zn}$ supplement provided by bran was not available.

Many studies on pigs have shown that wheat and wheat bran $P$ are much better utilized than corn $\mathrm{P}$ but not as well utilized as inorganic $\mathrm{P}$ (Miracle et al., 1977 ; Pierce et al., 1977 ; Stober et al., 1979 ; Cromwell, 1979 ; Pointillart, Fontaine and Thomasset, 1984). The scale of the relative biological efficiency of $P$, established by Cromwell (1980) in relation to bone breaking resistance in growing pigs, assigns values of $0.48,0.29$ and 0.12 to wheat, wheat bran and corn, respectively, compared to the reference value of 1 attributed to monosodium phosphate. The true absorption percentage of wheat bran $\mathrm{P}$ labelled with ${ }^{32} \mathrm{P}$ was estimated at 37 vs 70 for disodium phosphate (Guéguen, Besançon and Rérat, 1968). Wheat bran $P$ is thus much better utilized by pigs than anticipated and this was confirmed by the work of Newton, Hale and Plank (1983) on pigs receiving longer-term (80-day) diets enriched with wheat bran. These authors noted an obvious decrease in $\mathrm{P}$ and $\mathrm{Mg}$ levels in the undigestible fraction of bran in the feces.

Our results also show that not only is wheat bran $\mathrm{P}$ well absorbed, but the presence of bran improves the utilization of $P$ of the corn-soybean diet. This confirms the observation of Collings et al. (1979) on pigs receiving a diet enriched with wheat middlings and might be explained by bran phytase (E.C. 3.1.3.8) intake (Pointillart, Fontaine and Thomasset, 1984).

Fewer studies have been carried out on the influence of wheat bran on $\mathrm{Ca}$ and $\mathrm{Zn}$ utilization in pigs. Our results concerning the unfavorable effect of bran on the percentage of apparent absorption of $\mathrm{Ca}$ (table 4) agree with those of Nicolaysen and Njaa (1951) and the more recent ones of Collings et al. (1979). If, on a long-term basis (80 days), Newton, Hale and Plank (1983) found no significant effect on apparent Ca absorption when 10 or $20 \%$ of wheat bran was incorporated, they did discover that $\mathrm{Ca}$ accumulated in the undigestible part of the bran recovered in the feces of the pigs. These authors also found a decrease in apparent $\mathrm{Zn}$ absorption and a high accumulation of $\mathrm{Zn}$ in the undigestible fraction of bran recovered in the feces. Moreover, the negative influence of phytic acid, abundant in bran, on $\mathrm{Zn}$ absorption is well known (Oberleas et al., 1962) and could be one of the main factors producing parakeratosis in pigs.

While the bran improves $\mathrm{P}$ and $\mathrm{Mg}$ utilization it decreases that of $\mathrm{Ca}$ and $\mathrm{Zn}$. The fact that $\mathrm{P}$ and $\mathrm{Mg}$ contents of bran are high may, to some extent, account for the amelioration of the balance of these two minerals. Furthermore, in vitro experiments show that bran binds $\mathrm{Ca}$ in high amounts but can only bind small amounts of $\mathrm{P}$ (Bagheri and Guéguen, unpublished data).

The diets containing $20 \%$ of bran increased cecal volume and the production of volatile fatty acids, favoring the release of the previously bound minerals. Indeed, the proportion of ultrafilterable $\mathrm{Ca}$ in the cecum increased by 2 to 3-fold with the bran, while the ultrafilterable $\mathrm{Mg}$ concentration remained high in the cecum and was not modified by the presence of bran (Guéguen, Bagheri and Rérat, 1981). Consequently, the overall effect of bran on mineral absorption also probably depends on the ability of the large intestine to absorb eventual 
available elements in the cecum. The capacity of the large intestine to absorb $\mathrm{Mg}$ is always high (Partridge, 1978a, b). For the other elements, we have shown (Guéguen, Bagheri and Rérat, 1981) that the hind gut absorbed a large part $(28 \%)$ of a dose of soluble ${ }^{32} \mathrm{p}$ administered into the cecum, while absorption of ${ }^{45} \mathrm{Ca}$ and ${ }^{65} \mathrm{Zn}$ was low $(8.5$ and $4.0 \%$, respectively).

It is tempting to extrapolate to humans the above results on pigs, neither species having intestinal active phytase. Many studies have demonstrated the unfavorable effect in man of the ingestion of wheat bran or whole wheat bread on the utilization of $\mathrm{Ca}$ (McCance and Widdowson, 1942 ; Reinhold et al., 1976 ; Campbell et al., 1976 ; Cummings et al., 1979) and Zn (Reinhold, 1971 ; Sandstrøm et al., 1980 : Sandberg et al., 1982). Zoppi et al. (1982) warned the risks of ingesting high doses of bran which have a negative effect on the utilization of some minerals in children. This problem is less serious, at least as concerns $\mathrm{Ca}$, when the diet includes enough dairy products (Sandstead et al., 1979), Ca balance then being little modified by the bran intake. However, as noted by Van Dokkum, Wesstra and Schippers (1982), the absence of effect of bran on mineral balance may simply be a result of increased dietary intake and not mean that the bran has no negative effect on mineral availability. Their results obtained on young adult men and using an experimental design similar to that of the present study, i.e. without mineral supplementation to equalize the intakes, also show that increasing mineral consumption with bran does not ameliorate $\mathrm{Ca}$ and $\mathrm{Zn}$ balances. Nevertheless, in disagreement with the results obtained in pigs, the very high intake of $\mathrm{Mg}$ with the bran-rich diets did not increase the retention of this mineral. This discrepancy might be due to the much higher contribution of bran to the total $\mathrm{Mg}$ intake with the human diets.

In conclusion, by increasing available $\mathrm{P}$ intake and decreasing $\mathrm{Ca}$ absorption, a bran-rich diet may aggravate the traditional $\mathrm{Ca}: \mathrm{P}$ imbalance of human diets (Guéguen, 1982) and it might be recommended to use dephytinized bran products (Andersson et al., 1983), or to add calcium salts to such a diet.

2. Effect of pectin. - Incorporating $2.5 \%$ of HM pectin into the diet did not markedly change the utilization of the minerals studied. In spite of a lower intake the amounts of $P$ and $\mathrm{Zn}$ absorbed and retained were unchanged (figs. 5,8 ). Moreover the decrease in absorbed and retained $\mathrm{Ca}$ and $\mathrm{Mg}$ paralleled the decrease in the ingested amounts (figs. 6, 7).

Compared to HM pectin, at equal mineral intakes, the LM pectin considerably decreased the absorption and retention of the minerals, giving negative $\mathrm{Ca}, \mathrm{Mg}$ and $\mathrm{Zn}$ balances. Considering that the intakes of $\mathrm{Mg}$ and $\mathrm{Zn}$ were high and exceeded the requirements, these negative balances are quite abnormal. The zero or negative values of apparent absorption of $\mathrm{Ca}, \mathrm{Mg}$ and $\mathrm{Zn}$ obtained with LM pectin are the expression of a large fecal endogenous loss. It is probable that the re-absorption of the endogenous cations in the intestine is also hindered by the presence of LM pectin.

Since dietary fibers can bind $\mathrm{Ca}$ ions in direct proportion to their uronic acid content (James, Branch and Southgate, 1978), pectins might be expected to have a high affinity for $\mathrm{Ca}$. Incubation trials using radioisotopes (Bagheri and 
Guéguen, unpublished data) have evidenced that the binding percentage is higher for Ca with LM $(94 \%)$ than with HM $(59 \%)$ pectin.

The effect of degree of pectin esterification could explain the absence of influence on mineral metabolism noted in the scarce studies done on humans (Cummings et al., 1979 ; Drews et al., 1979 ; Lei et al., 1980 ; Sandberg et al., 1983). According to Cummings et al. (1979), the lack of effect would be due to degradation of the pectin in the intestine, releasing previously retained minerals, or to the high esterification of the pectin. The latter explanation is the most plausible because the pectin used in their experiment was about $80 \%$ methoxylated. Furthermore, it is hardly likely that minerals, especially $\mathrm{Ca}$ and $\mathrm{Zn}$, would be well absorbed in the large intestine.

It thus seems prudent in human nutrition to avoid using low-esterified pectins which have a very unfavorable influence on mineral metabolism.

Reçu en novembre 1984. Accepté en mai 1985.

Acknowledgements. - This work was supported by a grant from the "Délégation Générale à la Recherche Scientifique et Technique, Nutrition humaine, n 8070113 ".

Résumé. Effet du son de blé et de la pectine sur l'absorption et la rétention du phosphore, du calcium, du magnésium et du zinc par le porc en croissance.

Dans deux expériences distinctes sur des lots de 4 porcs en croissance, pesant de 35 à $40 \mathrm{~kg}$, des bilans de $\mathrm{P}, \mathrm{Ca}, \mathrm{Mg}$ et $\mathrm{Zn}$ ont été réalisés après adaptation durant 3 semaines à chacun des régimes étudiés. Dans la première expérience un régime témoin à base de maìs et de tourteau de soja a été comparé à un régime contenant $20 \%$ de son de blé grossier (aux dépens du maïs), et donc plus riche en minéraux, les quantités de minéraux ingérées n'étant pas égalisées. Dans la seconde expérience, trois régimes ont été comparés : un régime témoin, un régime contenant $2,5 \%$ de pectine de pomme fortement estérifiée (HM) et un régime contenant $2,5 \%$ de pectine de pomme faiblement estérifiée (LM).

Le supplément de $\mathrm{P}$ et de $\mathrm{Mg}$ fourni par le son de blé est bien absorbé labsorption apparente) et retenu par le Porc. Par contre, malgré un apport alimentaire plus élevé, l'absorption de $\mathrm{Ca}$ et $\mathrm{Zn}$ n'est pas augmentée dans les lots recevant du son de blé. Ces résultats peuvent être expliqués par l'action de la phytase du son de blé et par la possibilité d'absorption de $\mathrm{P}$ et surtout de $\mathrm{Mg}$ (mais pas de $\mathrm{Ca}$ et $\mathrm{Zn}$ ) dans le gros intestin.

Comparée à la pectine HM qui agit relativement peu sur l'utilisation des minéraux, la pectine LM diminue très fortement l'absorption et la rétention de tous les éléments étudiés et conduit notamment à un bilan négatif de $\mathrm{Ca}, \mathrm{Mg}$ et $\mathrm{Zn}$. Le degré d'estérification de la pectine serait donc le principal facteur déterminant son effet sur la disponibilité des minéraux.

En conclusion, le son de blé est une bonne source de $\mathrm{P}$ et de $\mathrm{Mg}$ pour le Porc, et probablement aussi pour l'Homme, mais il peut avoir un effet défavorable sur l'utilisation de $\mathrm{Ca}$ et $\mathrm{Zn}$. La pectine faiblement estérifiée a une influence néfaste sur les bilans minéraux.

\section{References}

ANDERSSON H., NÄVERT B., BINGHAM S. A., ENGLYST H. N., CUMMINGS J. H., 1983. The effects of breads containing similar amounts of phytate but different amounts of wheat bran on calcium, zinc and iron balance in man. Br. J. Nutr., 50, 503-510. 
BAGHERI S. M., GUÉGUEN L., 1981. Influence of wheat bran diets containing unequal amounts of calcium, magnesium, phosphorus and zinc upon the absorption of these minerats in rats. Nutr. Rep. Int., 24, 47-56.

BAGHERI S. M., GUÉGUEN L., 1982. Effects of wheat bran on the metabolism of calcium-45 and zinc-65 in rats. J. Nutr., 112, 2047-2051.

BAGHERI S. M., GUÉGUEN L., 1983. Influence des fibres alimentaires sur le métabolisme minéral. Cah. Nutr. Diét., 18, 77-83.

BRILLOUET J. M., THIBAULT J. F., 1981. Etude de fibres alimentaires de type fractions hémicellulosiques de son de blé, pectines et effets sur la vidange gastrique et la motricité intestinale chez l'Homme et l'animal (porc). C. R. fin d'étude action concertée, DGRST $N^{\circ}$ 79.7.1470.

BITAR K., REINHOLD J. G., 1972. Phytase and aikaline phosphatase activities in intestinal mucosae of rat, chicken, calf and man. Biochim. Biophys. Acta, 268, 442-452.

CAMPBELL B. J., REINHOLD J. G., CANNELL J. J., NOURMAND I., 1976. The effect of prolonged consumption of wholemeal bread upon metabolism of calcium, magnesium, zinc and phosphorus of two young american adults. Pahlavi Med. J., 7, 1-17.

COLLINGS G. F., ERICKSON J. P., YOKOHAMA M. T., MILLER E. R., 1979. Effect of wheat middlings on fiber digestibility, serum cholesterol and glucose and fecal bile acids in pigs. $J$. anim. Sci., 49, 528-534.

CROMWELL G. L., 1979. Availability of phosphorus in feedstuffs for swine. Proc. Dist. Feed Res. Conf., 34-40.

CROMWELL G. L., 1980. Biological availability of phosphorus for pigs. Feedstuffs, 52, $n^{\circ}$ 9, 38-42.

CUMMINGS J. H., HILL M. J., JIVRAJ T., HOUSTON H., BRANCH W. J., JENKINS D. J. A., 1979. The effect of meat protein and dietary fiber on colonic function and metabolisms. I. Changes in bowel habit, bile acid excretion, and calcium absorption. Am. J. clin. Nutr., 32, 2086-2093.

CUMMINGS J. H., SOUTHGATE D. A. T., BRANCH W. J., WIGGINS H. S., HOUSTON H., JENKINS D. J. A., JIVRAJ T., HILL M. J., 1979. The digestion of pectin in the human gut and its effect on calcium absorption and large bowel function. Br. J. Nutr., 41, 477-485.

DAVIES N. T., HRISTIC V., FLETT A., 1977. Phytate rather than fiber in bran as the major determinant of zinc availability to rats. Nutr. Rep. int., 15, 207-214.

DREWS L. M., KIES C., FOX H. M., 1979. Effect of dietary fiber on copper, zinc and magnesium utilization by adolescent boys. Am. J. clin. Nutr., 32, 1893-1897.

GUÉGUEN L., 1982. Les phosphates dans l'alimentation humaine. Méd. Nutr., 18, 237-245.

GUÉGUEN L., BAGHERI S. M., RÉRAT A., 1981. Influence of wheat bran on the intestinal absorption of minerals in the pig. Role of the hind gut. Proc. XI/th int. Congr. Nutr. San Diégo, U.S.A. (Abstr.).

GUÉGUEN L., BESANÇON P., RÉRAT A., 1968. Utilisation digestive, cinétique de l'absorption et efficacité de la rétention du phosphore phytique chez le Porc. Ann. Biol. anim. Biochim. Biophys., 8, 273-280.

GUÉGUEN L., PEREZ J. M., 1981. A re-evaluation of recommended dietary allowances of calcium and phosphorus for pigs. Proc. Nutr. Soc., 40, 273-278.

JAMES W. P. T., BRANCH W. J., SOUTHGATE D. A. T., 1978. Calcium binding by dietary fibre. Lancet, 1, 638-639.

LEI K. Y., DAVIS M. W., FANG M. M., YOUNG L. C., 1980. Effect of pectin on zinc, copper and iron balances in humans. Nutr. Rep. Int., 22, 459-466.

MCCANCE R. A., WIDDOWSON E. M., 1942. Mineral metabolism of healthy adults on white and brown bread dietaries. J. Physiol., 101, 44-85.

Mellanby E., 1921. Spec. Rep. Ser. med. Res. Counc. London, n 16.

MIRACLE G. L., CROMWELL G. L., STAHLY T. S., KRATZER D. O., 1977. Availability of phosphorus in corn, wheat and soybean meal for pigs. J. anim. Sci, 45, (Abstr.) (Supp. 1), 101.

NEWTON G. L., HALE O. M., PLANK C. O., 1983. Effect of wheat bran in practical diets on mineral absorption by pigs at low ages. Can. J. anim. Sci., 63, 399-468.

NICOLAYSEN R., NJAA L. R., 1951. Investigation on the effect of phytic acid on the absorption of calcium, in rats, pigs and men. Acta physiol. scand., 22, 246-259.

OBERLEAS D., 1971. The determination of phytate and inositol phosphates. Methods biochem. Anal., 20, 87-101. 
OBERLEAS D., MUHRER M. E., O'DELL B. L., 1962. Effects of phytic acid on zinc availability and parakeratosis in swine. J. anim. Sci., 21, 57-61.

PARTRIDGE I. G., 1978a. Studies on digestion and absorption in the intestines of growing pigs. 3. Net movements of mineral nutrients in the digestive tract. Br. J. Nutr., 39, 527-537.

PARTRIDGE I. G., 1978b. Studies on digestion and absorption in the intestines of growing pigs. 4. Effects of dietary cellulose and sodium levels on mineral absorption. Br. J. Nutr., 39, 539545.

PHANDIS A. D., SOHONIE K., 1974. The study of Ca and P metabolism of rats fed paddy diets by balance sheet method and bone ash analysis. Part. IV. Ind. J. Nutr. Diet., 11, 342-349.

PIERCE A. B., DOIGE C. E., BELL J. M., OWEN B. D., 1977. Availability of phytate phosphorus to the growing pig receiving isonitrogenous diets based on wheat or corn. Can. J. anim. Sci., 57, 573-583.

POINTILLART A., FONTAINE N., THOMASSET M., 1984. Phytate phosphorus utilization and intestinal phosphates in pigs fed low phosphorus : wheat or corn diets. Nutr. Rep. Int., 29, 473-483.

REINHOLD J. G., 1971. High phytate content of rural Iranian bread: a possible cause of human zinc deficiency. Am. J. clin. Nutr., 24, 1204-1206.

REINHOLD J. G., HEDAYATI H., LAHIMGARZADEH A., NASR K., 1973. Zinc, calcium, phosphorus, and nitrogen balances of Iranian villagers following a change from phytate-poor to phytate-rich diets. Eco. Food Nutr., 2, 157-162.

REINHOLD J. G., ISMAIL-BEIGI F., FARADJI F., 1975. Fibre vs. phytate as determinant of the availability of calcium, zinc and iron of breadstuffs. Nutr. Rep. Int., 12, 75-85.

REINHOLD J. G., FARADJI B., ABADI P., ISMAIL-BEIGI F., 1976. Decreased absorption of calcium, magnesium, zinc and phosphorus by humans due to increased fiber and phosphorus consumption as wheat bread. J. Nutr., 106, 493-503.

SANDBERG A. S., HASSELBLAD C., HASSELBLAD K., HULTEN L., 1982. The effect of wheat bran on the absorption of minerals in the small intestine. Br. J. Nutr., 48, 185-191.

SANDBERG A. S., AHDERINNE R., ANDERSSON H., HALLGREN B., HULTÉN L., 1983. The effect of citrus pectin on the absorption of nutrients in the small intestine. Human Nutr. clin. Nutr., 37 C. 171-183.

SANDSTEAD H. H., KLEVAY L. M., JACOB R. A., MUNOZ J. M., LOGAN G. M., RECK S. J., DINTZIS F. R., INGLETT G. E., SHUEY W. C., 1979. Effects of dietary fiber and protein level on mineral element metabolism, 147-156. In INGLETT G. E., Dietary fibers : chemistry and nutrition. Acad. Press Inc., New York.

SANDSTRØM B., ARVIDSSON B., CEDERBLAD A., BJORN-RASMUSSEN E., 1980. Zinc absorption from composite meals. I. The significance of wheat extraction rate, zinc, calcium and protein content in meals based on bread. Am. J. clin. Nutr., 33, 739-745.

SNEDECOR G. W., COCHRAN W. G., 1967. Statistical methods, lowa State University Press, lowa.

STOBER C. R., CROMWELL G. L., STAHLY T. S., 1979. Availability of phosphorus in corn and barley for the pig. J. anim. Sci., 49, (Abstr.) (supp. 1), 97-98.

VAN DOKKUM W., WESSTRA A., SCHIPPERS F. A., 1982. Physiological effects of fibre-rich types of bread. I. The effect of dietary fibre from bread on the mineral balance of young men. Br. J. Nutr., 47, 451-460.

WALKER A. R. P., FOX F. W., IRVING J. T., 1948. Studies in human mineral metabolism. 1. The effect of bread rich in phytate phosphorus on the metabolism of certain mineral salts with special reference to calcium. Biochem. J., 42, 452-462.

WILLS M. R., DAY R. C., PHILLIPS J. B., BATEMAN E. C., 1972. Phytic acid and nutritional rickets in immigrants. Lancet, 1, 771-773.

WISE A., GILBURT D. J., 1982. Phytate hydrolysis by germ-free and conventional rats. Appl. environ. Microbiol., 43, 753-756.

ZOPPI G., GOBIO-CASALI R., DEGANELLO A., ASTOLFI R., SACCOMANI F., CECCHETTIN M., 1982. Potential complications in the use of wheat bran for constipation in infancy. $J$. Pediatr. Gastroenterol., 1, 91-95. 